\title{
PENGARUH EKSTRAK ALANG-ALANG, BABADOTAN DAN TEKI TERHADAP PENYAKIT ANTRAKNOSA PADA BUAH PISANG KULTIVAR CAVENDISH
}

\author{
Intan Zahara Arie ${ }^{1}$, Joko Prasetyo ${ }^{2}, \&$ Efri $^{2}$ \\ MahasiswaJurusan Agroteknologi FakultasPertanianUniversitas Lampung \\ DosenJurusan Agroteknologi FakultasPertanianUniversitas Lampung \\ Jl. Prof. Dr. Soemantri Brodjonegoro No. 1 Bandar Lampung 35145
}

\begin{abstract}
ABSTRAK
Penelitian ini bertujuan untuk mengetahui pengaruh ekstrak alang-alang (Imperata cylindrica), teki (Cyperus rotundus), dan babadotan (Ageratum conyzoides) terhadap pertumbuhan dan sporulasi Colletotrichum musae. Penelitian juga bertujuan mengetahui pengaruh ekstrak alang-alang, teki dan babadotan terhadap keparahan penyakit antraknosa secara in vivo. Penelitian dilaksanakan di Laboratorium Penyakit Tumbuhan, Fakultas Pertanian, Universitas Lampung, dari bulan Juni sampai dengan September 2014. Percobaan disusun menggunakan Rancangan Acak Lengkap dengan 5 (lima) perlakuan dan 6 (enam) ulangan. Lima perlakuan tersebut yaitu kontrol, iprodion 50\%, esktrak teki, babadotan, dan alang-alang. Data yang diperoleh selanjutnya dianalisis dengan menggunakan sidik ragam dan kemudian dilanjutkan dengan uji BNT 5\%. Hasil penelitian menunjukkan bahwa ekstrak teki, babadotan dan alang-alang dapat menekan pertumbuhan, sporulasi $C$. musae secara invitro dan keparahan penyakit antraknosa pada buah pisang secara in-vivo. Ekstrak teki dan babadotan lebih efektif dalam menekan pertumbuhan, sporulasi $C$. musae dan keparahan penyakit antraknosa pada buah pisang. Ekstrak teki dan babadotan menunjukkan keefektifitasan yang sebanding dengan fungisida iprodion 50\% dalam menekan keparahan penyakit antraknosa pada buah pisang.
\end{abstract}

Kata kunci: antraknosa, Ageratum conyzoides, Colletotrichum musae, Ekstrak Cyperus rotundus, Imperata cylindrica,

\section{PENDAHULUAN}

Pisang (Musa paradisiaca L.) merupakan tanaman yang berasal dari kawasan Asia Tenggara, termasuk Indonesia.Pisang juga merupakan jenis buah yang langsung dapat dimakan setelah buah pisang masak (Nuryani \& Soedjono, 1999).Penyebaran tanaman pisang hampir merata di seluruh dunia, yaitu meliputi daerah tropis dan subtropis (Suyanti \&Supriyadi,2008).

Pisang merupakan produk hortikultura yang mempunyai arti penting bagi peningkatan gizi masyarakat karena buahnya merupakan sumber vitamin (A, B1dan C), mineral (kalium, natrium, chlor, magnesium, posfor) dan karbohidrat $25 \%$ yang mudah dicerna (Nuryani \& Soedjono, 1999). Menurut Departemen Pertanian (2004),permintaan buahpisang di Indonesia pada tahun 2005 mengalami peningkatan $32,5 \%$ atau dengan total konsumsi di Indonesia sekitar 10,3 juta ton.

Salah satu kendala utama dalam budidaya tanaman pisang adalah penyakit antraknosa. Penyakit antraknosa disebabkan oleh Colletotrichum musae (Semangun, 2000). Penyakit antraknosa merupakan penyakit terpenting pada buah pisang, karena pathogen tersebut dapat menyerang buah pisang yang masih muda maupun buah yang sudah matang.Gejala serangan pathogen ini ada pada buah pisang yaitu berupa bintikbintik kecil kehitaman,yang kemudian berkembang meluas kearah ujung buah. Gejala ini selanjutnya terus berkembang cepat membentuk noda dan menyatu dengan noda lainnya sehingga membentuk noda yang sangat besarsehingga buah pisang tersebut tidak menarik untuk dikomsumsi (Rumah lewang \&Amanupunyo, 2012).

Perkembangan penyakit antraknosa pada buah pisang dapat diatasi dengan menggunakan fungisida sintetis berbahan aktif iprodion $50 \%$, namun penggunaan fungisidasintetis yang tidak bijaksana atau terus-menerus, dapat menimbulkan dampak buruk terhadap kesehatan manusia, terhadap kualitas lingkungan dan berpengaruh pada resistensi patogen. Untuk mengurangi dampak negatif tersebut, maka diperlukan pengendalian penyakit yang ramah lingkungan, misalnya menggunakan fungisida yang berasal dari tanaman yaitu fungisida nabati.

Fungisida nabati adalah senyawa pembunuh jamur yang bahan dasarnya dari tumbuhan. Penggunaan fungisida nabati dapat menghambat perkembangan 
penyakit, aman bagi konsumen, lingkungan karena mudah terurai dan jugatidak meninggalkan residu pada produk pertanian (Sudarmo, 2005). Fungisida nabati memiliki potensi menekan penyakit antraknosa pada buah pisang, karena fungisida nabati mengandung bahan aktif yang bisa menghambat pertumbuhan patogen. Senyawasenyawa aktif tersebut mampu menekan pertumbuhan patogen.Menurut Sekar sari (2013), minyak atsiri dapat berperan sebagai antibakteri dan antifungi.

Tumbuhan yang dapat digunakan sebagai fungisida nabati antara lain alang-alang (Imperatacylindrica), teki (Cyperusrotundus) dan babadotan (Ageratum conyzoides). Tumbuhan ini mengandung senyawa seperti sineol, minyak atsiri dan alkaloid, yang berperan sebagai fungisida nabati.Berdasarkan uraian tersebut maka dilakukan penelitian tentang efektivitas ekstrak alang-alang, teki dan babadotan untuk mengendalikan penyakit antraknosa pada buah pisang Cavendish.

\section{METODE PENELITIAN}

Waktu dan Tempat Penelitian. Penelitian ini dilaksanakan dari bulan Juni 2014 sampai dengan September 2014 di Laboratorium Penyakit Tanaman, Fakultas Pertanian Universitas Lampung.

Alat dan Bahan. Alat-alat yang digunakan dalam penelitian ini adalah cawan petri, haemacytometer, bunsen, tabung reaksi, timbangan, gelas ukur, pipet tetes, pinset, korek api, LAF, mikroskop, oven, autoclave, rotamixer, labu erlenmeyer, nampan, alat tulis, jarum ose, blender, mikropipet, kaca preparat penggaris, alumunium foil, plastic cling wrap, pinset, dan label.

Bahan utama yang digunakan adalah buah pisang 'Cavendish', yang diperoleh dari PT. Nusantara Tropical Farm Sedangkan pada bahan yang lain yang di gunakan adalah biakan murni $C$. musae, ekstrak alang-alang, teki, babadotan , dan Fungisida Iprodion 50\%, alkohol, aquades, media PDA, antibiotik, dan $\mathrm{NaOCl} 0,5 \%$.

Metode Penelitian. Penelitian ini akan menggunakan Rancangan Acak Lengkap (RAL) dengan 5 perlakuan dan 6 ulangan. Perlakuan terdiri dari kontrol (P0), ekstrak alang-alang(P1), babadotan (P2), teki (P3), dan fungisida Iprodion $50 \%$ (P4). Penelitian ini dilaksanakan dalam 2 tahap pengujian yaitu uji penghambatan ekstrak gulma dan fungisida kimia terhadap pertumbuhan $C$. musae secara in-vitro dan uji pengaruh aplikasi ekstrak alang-alang, teki , babadotan , dan fungisida Iprodion 50\% terhadap penyakit antraknosa pada buah pisang secara in- vivo. Data yang diperoleh dianalisis dengan sidik ragam, lalu dilanjutkan dengan membandingkan nilai tengah dengan uji beda nyata terkecil (BNT) pada taraf 5\%.

\section{Pelaksanaan Penelitian}

Pembuatan Media Potato Dextrose Agar (PDA). Dalam pembuatan media PDA dibutuhkan air aquades sebanyak 1 liter, $20 \mathrm{~g}$ agar, $20 \mathrm{~g}$ gula pasir, dan $200 \mathrm{~g}$ kentang. Kentang dipotong kecil-kecil lalu direbus didalam 1 liter air sambil diaduk-aduk,selajutnya rebusan bahan-bahan tersebut disaring ke dalam tabung erlenmeyer. Tabung erlenmeyer yang berisikan PDA diberi bahan lain dan disterilkan dengan menggunakan autoklaf pada suhu $1210 \mathrm{C}$ dan tekanan $1 \mathrm{~atm}$ selama \pm 30 menit. Setelah itu proses sterilisasi selesai, media PDA didiamkan hingga dingin ataupun sampai hangat kuku kemudian ditambah 1,4 ml asam laktat.

Penyiapan biakan murni $C$. musae. Pada bagian buah pisang yang mempunyai gejala penyakit antraknosa diambil lalu diisolasikan. Isolasi dilakukan dengan cara bagian buah dipotong kecil-kecil ukuran $2 \times 2 \mathrm{~mm}$ diantara bagian yang sehat dan sakit, kemudian direndam dalam larutan $\mathrm{NaOCl}$ 0,5\% selama 1 menit, lalu ditiriskan atau dikering angin. Setelah kering, 3 atau 4 buah potongan dadu diletakkan dalam cawan yang berisikan media PDA. Selanjutnya C.musae yang tumbuh dimurnikan kembali dalam media PDA yang lain.

Pembuatan Ekstrak Alang-alang, Teki, dan Babadotan. Alang-alang, teki dan babadotan masingmasing dicuci dengan air mengalir lalu dikeringkan dengan suhu kamar. Bahan tersebut masing-masing ditimbang sebanyak $100 \mathrm{gr}$, setelah itu diblender dan dihomogenkan dalam $100 \mathrm{ml}$ aquades. Komposisi bahan dan aquades yaitu $1: 1,100 \mathrm{gr}$ bahan dan $100 \mathrm{ml}$ aquades. Cairan yang diperoleh lalu disaring dengan empat lapis kain kasa steril. Semua ekstrak diuji dengan konsentrasi 10\% (v/v)(Suryaningsih \& Hadisoeganda, 2004). Selain fungisida nabati, digunakan juga fungisida sintetis yang berbahan aktif Iprodion 50\% sebagai pembanding.

\section{Pengujian Ekstrak Tanaman}

Pengujian Secara In-vitro. Perlakuan pertama dilakukan secara in-vitro dengan menguji daya hambat ekstrak tumbuhan terhadap perkembangan C.musae pada media PDA. Media didinginkan dan dituang kedalam cawan petri sebanyak $9 \mathrm{ml}$ selanjutnya ditambahkan ekstrak tanaman yang uji sebanyak $1 \mathrm{ml}$ sehingga konsentrasinya $10 \%(\mathrm{v} / \mathrm{v})$ dan menjadi homogen 
dalam satu media tersebut. Biakan murni diambil dengan bor gabus berdiameter $0,5 \mathrm{~cm}$ lalu diletakkan di tengahtengah cawan petri, kemudian diinkubasi pada suhu kamar.

Pengujian Secara In-vivo. Perlakuan kedua merupakan uji pengaruh aplikasi ekstrak alang-alang, teki, dan babadotan terhadap penyakit antraknosa pada buah pisang 'Cavendish'. Buah pisang yang sehat pertama-tama disterikan dengan menggunakan alkohol $70 \%$ setelah itu buah pisang, dilukai dengan jarum sebanyak 50 sayatan lalu diaplikasikan dengan ekstrak tanaman uji konsentrasi 10\% (v/v)pada buah pisang. Kemudian diinokulasikan dengan C. musae di kulit pisang yang sudah di lukai dengan cara di semprotkan dengan $C$. musae. Selanjutnya buah pisang tersebut diinkubasi pada suhu kamar.

\section{Pengamatan}

Pengamatan Uji In-vitro. Pengamatan uji in-vitro dilakukan pada pertumbuhan koloni C.musae yang tumbuh pada media tersebut. Pengamatan ini dilakukan setiap hari. Pengamatan dapat dihentikan apabila perkembangan salah satu koloni jamur ini telah mencapai pinggiran petri. Variabel yang akan diamati adalah diameter pertumbuhan koloni C.musae pada media PDA dengan rumusan sebagai berikut :

$$
\mathrm{D}=\frac{\mathrm{D} 1+\mathrm{D} 2}{2}
$$

Keterangan: $\mathrm{D}=$ Diameter koloni $(\mathrm{cm}), \mathrm{D} 1=$ Diameter C. musae arah ke atas (cm), D2= Diameter C. musae arah ke samping $(\mathrm{cm})$.

Sedangkan penghitungan kerapatan spora dilakukan dengan cara isolat diencerkan dengan aquades sampai pengenceran mencapai $10^{6}$, lalu larutan tersebut diteteskan pada kotak hitung haemocytometer setelah itubditutup dengan menggunakan kaca objek. Kemudian diamati dan dihitung jumlah spora yang ada pada kotak hitung sedang dibawah mikroskop, sedangkan kerapatan spora dapat dihitung dengan menggunakan haemacytometer:

$$
\mathrm{K}=\text { Jumlah spora } x 0,25 \times 10^{6}
$$

Keterangan

$\mathrm{K}=$ Kerapatan spora per $\mathrm{ml}$ larutan

$0,25=$ Faktor koreksi penggunaan kotak sampai skala kecil pada haemacytometer
Pengamatan Uji in vivo. Parameter yang diamati dalam percobaan ini adalah menggunakan persentase keparahan penyakit. Pengamatan dilakukan setiaphari setelah aplikasi dengan cara mengamati gejala pada buah pisang ini dengan menggunakan plastic wrap. Buah pisang yang bergejala dibungkus dengan menggunakan plastic wrap dengan menggunakan spidol di atasnya, lalu plastic wrap yang sudah digambar luas gejalanya dihitung menggunakan millimeter blok.

Variable yang diamati adalah keparahan penyakit (\%) dihitung dengan rumus :

$$
\mathrm{KP}=\frac{\text { Luasdaerahyangbergejala }}{\text { Luaspermukaarkeseluruhn buahpisang }} \times 100 \%
$$

\section{HASIL DAN PEMBAHASAN}

Hasil penelitian secara in-vitro menunjukkan bahwa ekstrak teki, babadotan dan alang-alang berpengaruh dalam menekan pertumbuhan dan sporulasi C. musae, diantara semua perlakuan ekstrak teki yang memiliki kemampuan yang paling efektif dalam menekan pertumbuhanC. musae dan secara in-vivo menunjukkan bahwa ekstrak teki, babadotan dan alang-alang berpengaruh dalam menekan keparahan penyakit antraknosa pada buah pisang. Bahkan ekstrak teki dan babadotan menunjukkan keefektifitasan yang sama dengan iprodion $50 \%$.

\section{Pengaruh ekstrak tumbuhan terhadap} pertumbuhan dan kerapatan spora C.musae secara In Vitro. Hasil analisis ragam menunjukkan bahwa semua perlakuan berpengaruh nyata dalam menekan pertumbuhan koloni C. musae secara in-vitro. Berdasarkan hasil uji lanjut BNT (beda nyata terkecil) semua perlakuan pada pengamatan ke-2 sampai 7 hsa (hari setelah aplikasi) menunjukkan pengaruh yang berbeda dengan kontrol dalam menekan pertumbuhan C.musae, kecuali ekstrak alang-alang menunjukkan pengaruh yang tidak konsisten yaitu pada pengamatan hari ke-4 dan 5 (pengaruhnya tidak beda dengan kontrol). Ekstrak babadotan dan teki menunjukkan pengaruh yang berbeda dengan kontrol, tetapi ekstrak teki cenderung menunjukkan pengaruh yang lebih baik walaupun tidak seefektif iprodion 50\% (Tabel 1).

Ekstrak teki, babadotan dan alang-alang berpengaruh dalam menekan pertumbuhan dan sporulasi C. musae.Hal ini disebabkan karena ekstrak teki mengandung senyawa alkaloid, flavonoid, tanin, saponin, minyak atsiri, seskuiterpenoid (Fridiana, 2012). Ekstrak 
Tabel 1. Pengaruh ekstrak gulma terhadap rata-rata diameter $(\mathrm{cm})$ koloniC.musae pada media PDA

\begin{tabular}{lllllll}
\hline \multirow{2}{*}{ Perlakuan } & \multicolumn{7}{c}{ Rerata diameter $(\mathrm{cm})$ pada hari ke- } \\
\cline { 2 - 7 } & \multicolumn{1}{c}{2} & \multicolumn{1}{c}{3} & \multicolumn{1}{c}{5} & \multicolumn{1}{c}{6} & 7 \\
\hline Kontrol & $0,2 \mathrm{a}$ & $0,63 \mathrm{a}$ & $1,45 \mathrm{a}$ & $2,42 \mathrm{a}$ & $3,2 \mathrm{a}$ & $4,08 \mathrm{a}$ \\
Alang-Alang & $0,03 \mathrm{~b}$ & $0,23 \mathrm{~b}$ & $1,22 \mathrm{ab}$ & $2,07 \mathrm{a}$ & $2,71 \mathrm{~b}$ & $3,74 \mathrm{~b}$ \\
Babadotan & $0 \mathrm{~b}$ & $0,15 \mathrm{bc}$ & $1,04 \mathrm{bc}$ & $1,13 \mathrm{~b}$ & $2,38 \mathrm{c}$ & $2,90 \mathrm{c}$ \\
Teki & $0 \mathrm{~b}$ & $0,1 \mathrm{bc}$ & $0,9 \mathrm{c}$ & $0,95 \mathrm{~b}$ & $2,14 \mathrm{~d}$ & $2,28 \mathrm{~d}$ \\
Iprodion $50 \%$ & $0 \mathrm{~b}$ & $0 \mathrm{c}$ & $0 \mathrm{~d}$ & $0 \mathrm{c}$ & $0 \mathrm{e}$ & $0 \mathrm{e}$ \\
F Hitung & $18,03 * *$ & $7,41^{* *}$ & $32,98 * *$ & $68,97 * *$ & $677,1 * *$ & $670,16 * *$ \\
\hline BNT & 0,06 & 0,26 & 0.32 & 0,36 & 0,18 & 0,30 \\
\hline
\end{tabular}

Keterangan: Angka dalam kolom yang diikuti huruf berbeda menunjukan perbedaan yang nyata pada setiap uji BNT taraf 5\% . Pengolahan data angka didalam kolom diolah dengan menggunakan uji tranformasi $(\mathrm{x}+1)$.

babadotan dapat berfungsi sebagai fungisida nabati karena mengandung senyawa minyak atsiri, saponin, flovanoid, polifenol, HCN, alkaloid,dan kumarin (Setiawati et al., 2008). Ekstrak alang-alang juga dapat menekan pertumbuhan $C$. musae, karena alang-alang mengandung alkaloid, flavonoid, mannitol, asam malat, asam sitrat, coixol, arundoin, silindrin, fernerol, simiarenol, anemonin, esin, alkali, saponin, taninin, dan polifenol (Gusmarini, 2013).

Ekstrak teki, babadotan dan alang-alang mengandung senyawa alkaloid, flavonoid dan minyak atsiri.Menurut Rahayu \& Rahayu(2009) alkaloid mampu menekan pertumbuhan jamur dan dapat merusak komponen yang ada di dalam sel jamur dengan cara mendenaturasi protein sehingga dapat menyebabkan membranes lisis dan mati, sedangkan menurut Soetanet al. (2006) flavonoid dapat menganggu membrane sel jamur dengan cara membentuk protein ekstraseluler dan merusak dinding sel jamur. Minyak atsiri memiliki daya racun yang berfungsi sebagai fungisida nabati dan mengakibatkan rusaknya permeabilitas membrane sel jamur (Ridawatiet al., 2001).

Perlakuan yang paling efektif antara teki, babadotan dan alang-alang dalam menekan pertumbuhan C. musae adalah ekstrak teki, karena teki mengandung seskuiterpenoid yang tidak ada pada ekstrak babadotan dan alang-alang. Menurut Monika (2014) Seskuiterpenoid merupakan senyawa yang dapat digunakan sebagai fungisida nabati untuk menghambat pertumbuhan jamur dan merusak membran nukleus sel jamur.

Berdasarkan hasil analisis ragam,terlihat bahwa semua perlakuan menunjukkan pengaruh yang nyata dalam menekan kerapatan spora. Hasil uji BNT,menunjukkan bahwa pengaruh perlakuan ekstrak teki,babadotan, alang-alang dan iprodion $50 \%$ berbeda nyata dibandingkan perlakuan kontrol. Pengaruh ekstrak alang-alang menujukkan perbedaan yang nyata dengan teki dan babadotan dalam menekan jumlah kerapatan spora (Tabel 2). Berdasarkan analisis data diameter

Tabel 2. Pengaruh ekstrak gulma terhadap rata-rata jumlah kerapatan spora koloni $C$. musae.

\begin{tabular}{lc}
\hline Perlakuan & Rata-rata jumlah kerapatan spora $\left(10^{11} / \mathrm{ml}\right)$ \\
\hline Kontrol & $6,08 \mathrm{a}$ \\
Alang-alang & $2,79 \mathrm{~b}$ \\
Babadotan & $1,65 \mathrm{c}$ \\
Teki & $1,15 \mathrm{c}$ \\
Iprodion $50 \%$ & $0 \mathrm{~d}$ \\
F Hitung & $928,9 * *$ \\
BNT & 0,15 \\
\hline
\end{tabular}

Keterangan: Angka dalam kolom yang diikuti huruf berbeda menunjukan perbedaan yang nyata pada setiap uji BNT taraf 5\% . Pengolahan data angka didalam kolom diolah dengan menggunakan uji tranformasi $\log +1$. 
koloni dan jumlah kerapatan spora, perlakuan yang menunjukkan hasil yang sejalan adalah perlakuan teki dan babadotan sehingga ekstrak teki dan ekstrak babadotan ini dapat dikatakan sebagai ekstrak yang terbaik dalam menekan pertumbuhan C.musae.

Ekstrak alang-alang kurang efektif dibandingkan dengan ekstrak teki dan babadotan, karena senyawa aktif yang dihasilkan oleh ekstrak alang-alang pada konsentrasi $10 \%$ (v/v) kurang maksimal dalam menekan pertumbuhan jamur C. musae. Pemberian ekstrak alang-alang dengan konsentrasi diatas $10 \%$ (v/v) diduga dapat menekan pertumbuhan jamur $C$. musae, hal ini berdasarkan hasil penelitian Watiet al. (2012) bahwa pemberian filtrat daun alang-alang pada konsentrasi $40 \%$ (v/v) menununjukkan kemampuan senyawa metabolit sekunder polifenol dan flovoindyang dapat menekan pertumbuhan miselium jamur Trichoderma sp.yang menjadikontaminasi pada media tanam jamur tiram putih (Pleurotus ostreatus).

\section{Keparahan Penyakit Antraknosa pada Pisang.} Hasil analisis ragam, menunjukkan bahwa perlakuan pada pengamatan hari ke-6 hsa sampai dengan hari ke8 hsa tidak berpengaruh terhadap keparahan penyakit antraknosa pada pisang. Pada hari ke-9 hsa perlakuan mulai terlihat berpengaruh nyata baik ekstrak teki, babadotan maupun iprodion 50\%. Pengaruh ekstrak alang-alang baru terlihat pada 11 hsa (Tabel 3) . Diantara semua perlakuan yang paling efektif adalah ekstrak teki dan babadotan. Bahkan ekstrak teki, dan babadotan menunjukkan keefektifitasan yang sama dengan iprodion $50 \%$.

Hasil penelitian secara in-vivo menunjukkan bahwa ekstrak teki, babadotan dan alang-alang berpengaruh dalam menekan keparahan penyakit antraknosa pada buah pisang. Kemampuan ekstrak teki, babadotan dan alang-alang dapat menekan keparahan penyakit antraknosa karena ekstrak babadotan, teki dan alang-alang mengandung alkaloid dan flavonoid. Flavonoid dan alkaloid diketehui dapat dijadikan bahan antifungi serta dapat berfungsi sebagai fungsida nabati (Kumalasari \& Sulistyani, 2011).

Hasil pengujian secara in-vivo menunjukkan bahwa perlakuan teki, babadotandanalang-alangdapat menekan keparahan penyakit antraknosa. Dari ketiga ekstrak gulma tersebut,terlihat bahwa ekstrak teki yang lebih efektif dalam menekan keparahan penyakit antraknosa bahkan ekstrak teki menunjukkan keefektifitasan yang sama dengan iprodion 50\%. Hal ini sejalan dengan penelitian Gusmarini (2013) menunjukan bahwa kemampuan ekstrak teki dan tumbuhan siam lebih efektif dalam menekan keparahan penyakit antraknosa pada daun dan buah cabai merah dibandingkan dengan ekstrak babadotandan alang-alang.

\section{KESIMPULAN DAN SARAN}

\section{Kesimpulan}

Dari hasil penelitian yang telah dilakukan dapat disimpulkan bahwa ekstrak teki, babadotan dan alangalang dapat menekan pertumbuhan dan sporulasi C.musae secara in-vitro.Ekstrak teki, babadotan dan alang-alang dapat menekan keparahan penyakit antraknosa (C.musae)pada buah pisang. Ekstrak teki dan babadotan lebih efektif dalam menekan pertumbuhan, sporulasi C. musaedan keparahan penyakit antraknosa pada buah pisang. Ekstrak teki dan

Tabel 3. Keparahan penyakit antraknosa pada buah pisang

\begin{tabular}{lcccccc}
\hline \multirow{2}{*}{ Perlakuan } & \multicolumn{7}{c}{ Keparahan Penyakit $(\%)$} \\
\cline { 2 - 7 } & 6 has & 7 has & 8 has & 9 has & 10 has & 11 hsa \\
\hline Kontrol & 0,07 & 2,4 & 3,32 & $12,2 \mathrm{a}$ & $27 \mathrm{a}$ & $44,17 \mathrm{a}$ \\
Alang-alang & 0,03 & 1,2 & 1,03 & $8,5 \mathrm{a}$ & $20,9 \mathrm{a}$ & $34,5 \mathrm{~b}$ \\
Babadotan & 0,03 & 0,9 & 0,82 & $1,4 \mathrm{~b}$ & $10,8 \mathrm{~b}$ & $19,54 \mathrm{c}$ \\
Teki & 0,02 & 0,6 & 0,32 & $0,8 \mathrm{~b}$ & $7,6 \mathrm{~b}$ & $14,65 \mathrm{c}$ \\
Iprodion 50\% & 0 & 0 & 1,1 & $2,3 \mathrm{~b}$ & $10,6 \mathrm{~b}$ & $16,63 \mathrm{c}$ \\
F Hitung & 0,46 tn & 0,54 tn & 1,32 tn & $8,56 * *$ & $13,92 * *$ & $20,76 * *$ \\
\hline BNT & - & - & - & 6,16 & 6,89 & 9,85 \\
\hline
\end{tabular}

Keterangan : Pengolahan data angka di dalam kolom diolah dengan menggunakan uji transformasi $\sqrt{(} x+0,5)$ dan

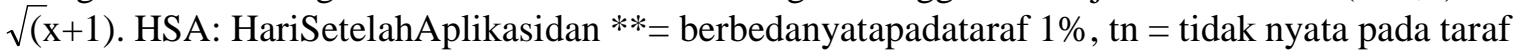
$5 \%$. 
babadotan menunjukkan keefektifitasan yang sebanding dengan fungisida iprodion $50 \%$ dalam menekan keparahan penyakit antraknosa pada buah pisang.

\section{Saran}

Berdasarkan hasil penelitian yang telah dilakukan, maka masih perlu dilakukan pengujian lebih lanjut mengenai senyawa-senyawa aktif ekstrak teki dan babadotan terhadap pertumbuhanC. musae dan keparahan penyakit antraknosa.

\section{DAFTAR PUSTAKA}

Departemen Pertanian. 2004.Pascapanen Pisang dan Pengolahannya. http://www.deptan.go.id. Diakses 09 januari 2015.

Fridiana, D. 2012. Uji Antiinflamasi Ekstrak Umbi Rumput Teki (Cyperus rotundusL.) pada Kaki Tikus Wistar Jantan yang Diinduksi Karagen. Skripsi Universitas Jember.

Gusmarini, M. 2013. Pengaruh Beberapa Jenis Ekstrak Tumbuhan terhadap Penyakit Antraknosa pada Tanaman Cabai Besar di Lapangan.Skripsi Universitas Lampung.

Kumalasari, E \& N. Sulistyani. 2011. Aktivitas Antifungi Ekstrak Etanol Batang Binahong (Anredera cordifolia (Tenore) Steen.) terhadap Candida albicans SertaSkrining Fitokimia. Jurnal Ilmiah Kefarmasian, 1(2): 51-62.

Monika, I. 2014. Uji Aktivitas Ekstrak Kencur terhadap Pengendalian Pertumbuhan Fusarium oxysporum dan Implementasinya dalam PembuatanFlipbook. Skripsi Universitas Tanjungpura Pontianak.

Nuryani\&Soedjono. 1999. BudidayaPisang.Dahara Prize. Semarang.

Rahayu, T \& T. Rahayu. 2009. Uji Antijamur Kombucha Coffee terhadap Candida albicans dan Tricophyton mentagrophytes. Jurnal Penelitian Sains \& Teknologi,10(1): 10-17.

Ridawati, B. S., L. Diuwati., W. Sjamsuridzal. 2012. Aktivitas Antifungal Minyak Atsiri Jinten Putih terhadap Candida parapsilosis SS25, C. orthopsilosis NN14,C. metapsilosis MP27, danC. etchellsii MP18. Makara, Sains 15(1): 58-62.
Rumahlewang, W \& H.R.D. Amanupunyo. 2012.Patogenisitas Colletotrichum musae Penyebab Penyakit AntraknosaPada Beberapa Varietas Buah Pisangurnal Ilmu Budidaya Tanaman, 1(1):77-81.

Semangun,H.2000. Ilmu Penyakit Tumbuhan. GadjahMada University Press. Yogyakarta.

Sekarsari, A. R. 2013. Pengaruh Beberapa Fungisida Nabati Terhadap Keterjadian Penyakit Bulai pada Jagung Manis (Zea mays saccharata). Jurnal Agrotek Tropika, 1(1):98-101.

Setiawati, S., R. Murtiningsih., N. Gunaeni, dan T. Rubiati. 2008. Tumbuhan Bahan Pestisida Nabati dan Cara Pembuatannya untuk Pengendalian OraganismePenggangu Tumbuhan (OPT). Prima Tani Balitsa.Hlm 16-17.

Soetan, K., M. A. Oyekunie., O. Aiyelaagbe., MA. Fafunso. 2006. Evaluation of the Antimicrobial Activity of Saponins Extract of Shorgum bicolor L. Moench.African Journal of Biotechnology, 5(23): 2405-2407.

Sudarmo, S. 2005. Pestisida Nabati Pembuatandan Pemanfaatannya. Kanisius : Yogyakarta.Hlm 4-5.

Suryaningih, E \&Hadisoeganda. 2004. Pestisida Botani Untuk Mengendalikan Hama dan Penyakit Sayuran. Pusat Penelitian dan Pengembangan Hortikultura, Bandung.

Suyanti \& Supriyadi, A. 2008. Pisang. Jakarta: Penebar Swadaya.

Wati, K. D., Yuliani., dan L.S. Budipramana. 2012. Pengaruh Pemberian Filtrat Daun Alang-Alang (Imperata cylindrica L.) terhadap Pertumbuhan Miselium JamurTrichodermaSp. yang Hidup pada Media Tanam Jamur Tiram Putih (Pleurotus ostreatus). LenteraBio, 1(2): 93-98. 